\title{
Weed Mapping Using Techniques of Precision Agriculture ${ }^{1}$
}

\author{
Mapeamento de Plantas Daninhas Utilizando Técnicas de Agricultura de Precisão
}

\author{
ROCHA, F.C. ${ }^{2}$, OLIVEIRA NETO, A.M. ${ }^{2}$, BOTTEGA, E.L. ${ }^{3}$, GUERRA, N. ${ }^{2}$, ROCHA, R.P. ${ }^{4}$, and \\ VILAR, C.C. ${ }^{5}$
}

\begin{abstract}
The aim of this study was to identify and map the weed population in a notillage area. Geostatistical techniques were used in the mapping in order to assess this information as a tool for the localized application of herbicides. The area of study is 58.08 hectares wide and was sampled in a fixed square grid (which point spaced $50 \mathrm{~m}$, 232 points) using a GPS receiver. In each point the weeds species and population were analyzed in a square with a $0.25 \mathrm{~m}^{2}$ fixed area. The species Ipomoea grandifolia, Gnaphalium spicatum, Richardia spp. and Emilia sonchifolia have presented no spatial dependence. However, the species Conyza spp., C. echinatus and E. indica have shown a spatial correlation. Among the models tested, the spherical model has shown had a better fit for Conyza spp. and Eleusine indica and the Gaussian model for Cenchrus echinatus. The three species have a clumped spatial distribution. The mapping of weeds can be a tool for localized control, making herbicide use more rational, effective and economical.
\end{abstract}

Keywords: Conyza spp., geostatistics, foci, no-tillage farming.

\begin{abstract}
RESUMO - Objetivou-se neste estudo identificar e mapear a população de plantas daninhas em uma área de plantio direto, utilizando técnicas geoestatisticas, com a finalidade de utilizar essa informação como ferramenta para a aplicação localizada de herbicidas. O trabalho foi realizado em propriedade com área de 58,08 hectares que utiliza sistema de plantio direto. Demarcou-se uma malha amostral, os pontos foram espaçados uniformemente e a amostragem de plantas daninhas foi feita em cada ponto, utilizando-se um gabarito de $0,25 \mathrm{~m}^{2}$. O caminhamento ponto-a-ponto foi realizado utilizando um receptor GPS. Conclui-se que as espécies Ipomoea grandifolia, Gnaphalium spicatum, Richardia spp. e Emilia sonchifolia não apresentaram dependência espacial. Conyza spp., Cenchrus echinatus e Eleusine indica apresentaram dependência espacial, sendo o modelo esférico o que melhor ajustou os dados de Conyza spp. e Eleusine indica e o modelo gaussiano o que melhor ajustou os dados de Cenchrus echinatus. As três espécies possuem distribuição espacial agregada. O mapeamento das plantas daninhas se apresenta como uma ferramenta para o controle localizado destas, tornando o uso de herbicida mais racional, eficaz e econômico.
\end{abstract}

Palavras-chave: Conyza spp., geoestatística, reboleiras, plantio direto.

\section{INTRODUCTION}

Chemical control has high efficiency, low cost and performance practicality. For this, herbicides with different spectra of action are used, designed to interrupt the growth and development of the weeds (Lorenzi, 2000). Carvalho et al. (2002) point out that the herbicides used for weed management before sowing of the crop are very important and widely used in the no-till farming system, especially the ones employed in management

1 Recebido para publicação em 3.10.2014 e aprovado em 3.11.2014.

2 Faculdade Integrado de Campo Mourão-PR, Brasil, <agro.rocha@hotmail.com>; ${ }^{3}$ Universidade Federal de Santa Catarina. Curitibanos-SC, Brasil; ${ }^{4}$ Universidade do Estado de Mato Grosso, Tangará da Serra-MT, Brasil, ${ }^{5}$ Universidade do Estado de Mato Grosso, Nova Xavantina-MT, Brasil. 
burndown such as glyphosate and paraquat, which show no residual effect for the ersatz culture to be implemented.

With increasing demand for food worldwide, companies and producers need to use large amounts of pesticides which, besides ensuring productivity gains, aiming to meet the needs of humanity, are able to profit from this economic activity. In this context, a way to use these pesticides properly is to apply them in a variable rate, namely, to apply them based on maps derived from field surveys or generated in real time. Thus, the producers, along with their technical assistants, can plan ahead and make the decisions accurately, providing considerable savings in herbicides, increased application efficiency and reduced environmental impact (Shiratsuchi et al., 2003).

In addition to the environmental and financial aspects, the application of herbicides, if performed in a localized form, rationalizes the use of these products. Shiratsuchi \& Fontes (2005) have stated that the mapping of weed populations, from geostatistical procedures, is an important ally in increased herbicide use efficiency and may cause a reduction in the volume applied around 22 to $44 \%$. In addition to saving resources by applying varying volumes depending on the infestation, the mapping of weed populations allows the monitoring of their evolution, which may contribute to the development of management strategies that reduce the competition period with the culture (Jaremtchuk et al., 2008).

In this context, the objective was to identify and map the population of weeds in a no-till area, using geostatistical techniques, in order to use such information in localized application of herbicides.

\section{MATERIALS AND METHODS}

The work was conducted at Santa Luzia farm, located in the municipality of Engenheiro Beltrão, PR. The property has the following geographical coordinates: latitude $23^{\circ} 46^{\prime} 04^{\prime \prime}$ south, longitude $52^{\circ} 20^{\prime} 50^{\prime \prime}$ west and altitude 440 meters. The soil of the area has been identified as clayey red oxisol (Embrapa, 2013). The local climate is classified as subtropical
Cfa, according to Köppen classification (IAPAR, 2011). The property adopts the no-till farming system, and crops of soybeans and corn are cultivated in first and second seasons, respectively.

The experimental area used was 58.08 hectares. A sampling area was marked, composed of 232 points, evenly spaced in 50 meters. The weed sample was taken at each sample point, using a $0.25 \mathrm{~m}^{2}$ fixed area. The point-to-point traversal was performed using a GPS receiver, model GPS Map, brand Garmin. Data collection was made on September 23, 24 and 25, 2013.

The weed species Conyza spp. (horseweed, butterweed or fleabane), Cenchrus echinatus (common names include buffelgrasses, sandburs, and sand spur), Ipomoea grandifolia (common names including morning glory, sweet potato, bindweed, moonflower etc.), Gnaphalium spicatum (cudweeds), Eleusine indica (Indian goosegrass, wiregrass, crowfootgrass), Richardia spp. (common names are tropical Mexican clover, Brazilian callalily, white-eye, and Brazil pusleypoaia) and Emilia sonchifolia (lilac tasselflower or cupid's shaving brush) were sampled at each point. In the sampling, the number of plants of each species was counted within the fixed area, which were later converted to plants by $\mathrm{m}^{-2}$. The identification manual of weeds authored by Lorenzi (2000) was used as a tool for species identification. Figure 1 shows the polygon area, with the sampling points used in the survey of weeds.

The amounts related to weed populations sampled in the study area were first submitted to exploratory analysis to verify the presence of disparate amounts and their influence on the measurements of position and dispersion. In this analysis, the critical threshold for outliers is defined from the interquartile range (DQ), calculated as the difference between the upper quartile and bottom quartile. The upper limit was defined by $(\mathrm{Q} 3+1.5 \times \mathrm{DQ})$ and the lower limit was defined by (Q1 - $1.5 \times \mathrm{DQ})$, where Q1 and Q3 represent the first and third quartiles, respectively (Libardi et al., 1996). After identification, a spatial location of these values within the sampling grid was held to assist in making a decision about the disposal or not of these outliers. 


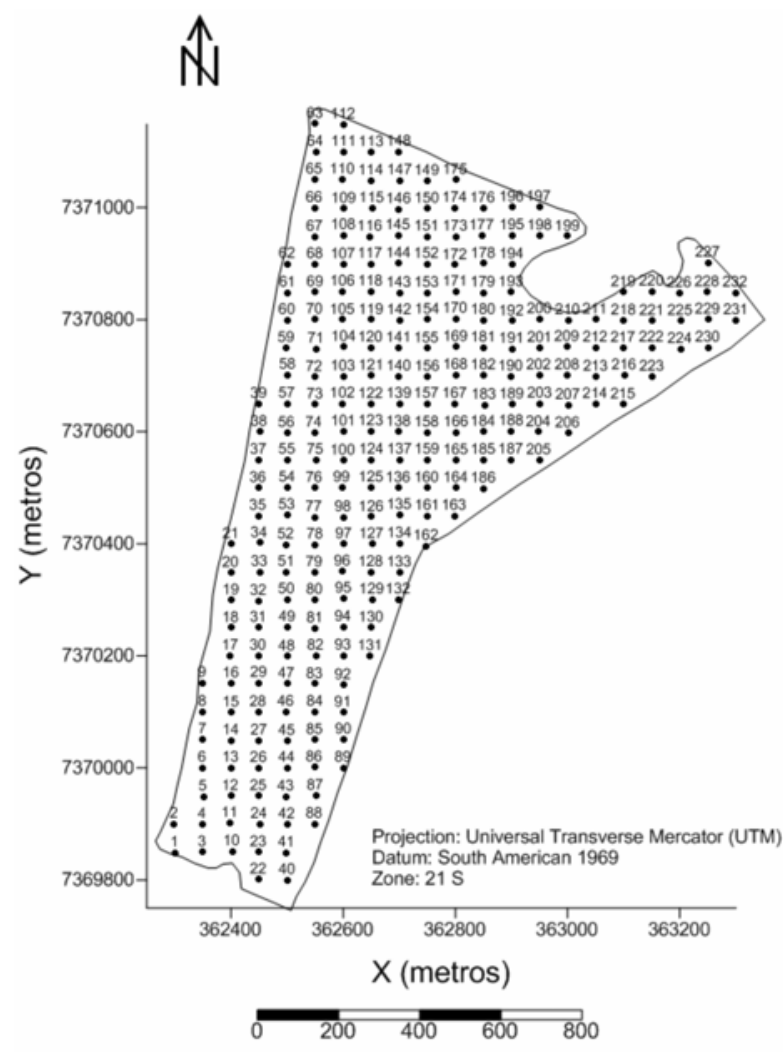

Figure 1 - Experimental area and location of sampling points used in the survey of weed.

Then the data were analyzed using descriptive statistics, calculating the mean, median, minimum, maximum, standard deviation, coefficient of variation, lower quartile and upper quartile, thus seeking to characterize them. To verify the spatial dependence of the variables, the geostatistical analysis was used, as proposed by Vieira (2000). The spatial dependence was assessed by semivariogram adjustments, assuming the stationarity of the intrinsic hypothesis, defined by Equation 1.

$$
\hat{\gamma}(h)=\frac{1}{2 N(h)} \sum_{i=1}^{N(h)}[Z(x i)-Z(x i+h)]^{2}
$$

where: $\hat{\gamma}(h)=$ semivariance due to the separation distance $(h)$ between pairs of points; $H=$ separation distance between pairs of points; and $N(h)=$ number of pairs of experimental points separated by a distance $h$.

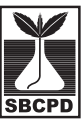

The semivariogram is represented by graph versus $h$. The Gaussian, spherical and exponential models were tested. The model that best represented the relationship between experimental semivariance and the $h$ distance was set, and the parameters were determined: nugget $\left(\mathrm{C}_{0}\right)$, baseline $\left(\mathrm{C}_{0}+\mathrm{C}\right)$ and range (A) effects. To choose the best adjustment model, the smallest sum of squares of the residue (SQR) and the highest coefficient of determination $\left(\mathrm{R}^{2}\right)$, as well as a cross-validation analysis (observed values versus estimated values) were used. The consideration of spatial dependence, according to Junqueira Júnior et al. (2008), enables the control of a portion of the random error and, thus, obtaining good results in estimates of values at unsampled sites.

The spatial dependence index (SDI) was determined and classified according to Zimback (2001), using Equation 2 and assuming the following intervals: low spatial dependence for SDI $<25 \%$, moderate for $25 \%<$ SDI $<75 \%$ and strong for SDI $>75 \%$.

$$
S D I=\left(\frac{C}{C_{0}+C}\right) 100
$$

where: $S D I=$ spatial dependency ratio; $C=$ semivariance contribution: $\left(C_{0}+C\right)-\mathrm{C}_{0}$; and $C_{0}+C=$ baseline.

The interpolation of the maps was done using ordinary kriging. For the estimates, 16 close neighbors and a search width equal to the range value found in the adjustment of the semivariogram were used. Grego \& Vieira (2005) point out that the construction of maps with the values obtained by kriging are important for verification and interpretation of spatial variability. The geostatistical analysis of the data is completed with the information shown on the maps, which is useful in decision-making.

Statistical analysis was performed using computer program Statistica, version 7 . The geostatistical analysis and the models of semivariogram of the attributes studied were adjusted using the computer program GS+, version 9. Thematic maps were generated using the program Surfer, version 10. 


\section{RESULTS AND DISCUSSION}

Table 1 shows the values for the descriptive statistics of the species studied after harvest of winter maize (milho safrinha) in the experimental area. According to the classification proposed by Warrick $\&$ Nielsen (1980), it is considered that values CV $<12 \%$ is low; $12 \% \leq \mathrm{CV} \leq 60 \%$ is average; and $\mathrm{CV}>60 \%$, is high. Thus, the descriptive statistical analysis (DSA) has shown that there was a high variability found among species of weeds, considering the coefficient of variation, since all the values were higher than $60 \%$. This result was already expected, because it is an analysis of data from the count of weeds, namely, a discrete variable, since there are places with high infestations and other places without the presence of weeds. This is due to its type of distribution in spots or foci, as seen in the maximum and minimum values.

Table 2 shows the parameters of the semivariograms adjusted to the theoretical models that best describe the spatial variability of the weeds studied.

Weeds I. grandifolia, G. spicatum, Richardia spp. and E. sonchifolia have not shown spatial dependence. When the absence of spatial dependence is total, it is called pure nugget effect. This effect shows that the spatial distribution of the attribute in the study area is homogeneous, random or else the sampling grid used does not have enough points to detect dependency, which, if any, will be manifested at distances less than the smallest gap between samples (Guimarães, 2004).

As for weeds Conyza spp., C. echinatus and $E$. indica, they have shown spatial dependence. The highest coefficient of determination observed for the model adjustment was 0.940 for species $C$. echinatus, and the lowest was 0.823 for E. indica. The model that showed the best fit of semivariance for Conyza spp. and E. indica was the spherical one. Regarding E. indica, a range of $163 \mathrm{~m}$ for the spherical model was observed. These results corroborate those found by Zanin et al. (1998), who demonstrated for Amaranthus spp. the best semivariogram adjustment in the spherical model with a range of 40 meters. The spherical model shows a range that increases to a certain point in time, from which the semivariance becomes constant, namely, limiting its area of influence for each of the samples (Carlin, 2010).

Table 1 - Descriptive statistics for the variable density of the seven species of weeds mapped. Engenheiro Beltrão, PR, 2013

\begin{tabular}{|l|c|c|c|c|c|c|c|c|}
\hline \multicolumn{1}{|c|}{ Specie } & Mean $\left(\mathrm{m}^{2}\right)$ & $\mathrm{Md}^{1 /}$ & Minimum & Maximum & $\mathrm{s}^{2 /}$ & $\mathrm{CV}(\%)^{3 /}$ & $\mathrm{QI}^{\frac{4 /}{}}$ & $\mathrm{QS}^{5 /}$ \\
\hline Conyza spp. & 40.0 & 32.0 & 0.0 & 140 & 31.9 & 79.9 & 32.0 & 58.0 \\
\hline C. echinatus & 1.8 & 0.0 & 0.0 & 28 & 4.6 & 250.1 & 0.0 & 0.0 \\
\hline I. grandifolia & 0.01 & 0.0 & 0.0 & 2 & 0.15 & 1133.3 & 0.0 & 0.0 \\
\hline G. spicatum & 1.1 & 0.0 & 0.0 & 36 & 3.9 & 353.9 & 0.0 & 0.0 \\
\hline E. indica & 0.11 & 0.0 & 0.0 & 6.0 & 0.6 & 578.5 & 0.0 & 0.0 \\
\hline Richardia spp. & 0.03 & 0.0 & 0.0 & 4.0 & 0.37 & 1074.7 & 0.0 & 0.0 \\
\hline E. sonchifolia & 0.07 & 0.0 & 0.0 & 4.0 & 0.27 & 756.62 & 0.0 & 0.0 \\
\hline
\end{tabular}

1/Median; ${ }^{2}$ Standard deviation; ${ }^{3 /}$ Coefficient of variation; ${ }^{4 /}$ Lower quartile; ${ }^{5 /}$ Upper quartile.

Table 2 - Parameters of the theoretical models of semivariance, adjusted for the seven species of weeds mapped. Engenheiro Beltrão, PR, 2013

\begin{tabular}{|l|c|c|c|c|c|c|}
\hline \multicolumn{1}{|c|}{ Specie } & Model & Range $(\mathrm{m})$ & $\mathrm{C} 0+\mathrm{C}^{1 /}$ & $\mathrm{C}^{2 /}$ & $\mathrm{SDI}^{\mathbf{3}^{\prime /}}$ & $\mathrm{R}^{24 /}$ \\
\hline Conyza spp. & Spherical & 128 & 1039 & 12 & 1.15 & 0.839 \\
\hline C. echinatus & Gaussian & 1068 & 48 & 14 & 29.16 & 0.940 \\
\hline E. indica & Spherical & 163 & 0.56 & 0.07 & 13.57 & 0.823 \\
\hline
\end{tabular}

1/Baseline; ${ }^{2 / N u g g e t ;}{ }^{3 /}$ Spatial dependency ratio; ${ }^{4 /}$ Coefficient of determination;5/ Pure nugget effect. 
For C. echinatus, the model that best fit was the Gaussian. This model is representative of extremely continuous phenomena, indicating a smooth variation in small observation distances, continuing from the phenomena studied at a the long-range (Bottega et al., 2013). According to Corá et al. (2004), low range values can influence the quality of the estimates, as few points are used for performing the interpolation. The range may still function as a default in assessing the choice of the minimum distance between sample points because, when considering half the value of the range, the detection of the spatial variability of the attribute under consideration is guaranteed without losing precision in estimates - this because the spatial continuity of the variable is retained (Carvalho \& Queiroz, 2002).

Table 3 shows the parameters of the crossvalidation of the theoretical models of semivariance adjusted for the weed population of the study area. The parameters shown are: regression coefficient, intercept $(\mathrm{Y})$, standard error (SE) and coefficient of determination $\left(\mathrm{R}^{2}\right)$.

Conyza spp., C. echinatus and E. indica have shown values of regression coefficient more distant from 1: 0.771, 0.584 and 0.887 , respectively. In relation to the regression coefficient, none of the species has shown values close to or equal to 1 . As for the coefficient of determination, $E$. indica has shown the highest value: 0.379. All species have shown a standard error close to zero, which shows that the adjusted model had a good accuracy in estimating the population of these species in non counted points, except Conyza spp., which has shown a value much greater than zero. Cross-validation analysis is extremely important for the choice of the theoretical model of semivariance that best describes the empirical semivariance of the data, because it allows the evaluator to plot in a dispersion chart of points the values observed versus estimated by the model, visually, practically and rapidly identifying less accurate points of the estimates made by the model adopted.

Based on the models of semivariance and considering the parameters set for the studied species, using ordinary kriging, the sampled values were interpolated in order to build maps of the spatial variability of the weeds studied. Figure 2 shows the maps of the area used for the survey of the weeds.

Figure 2 shows the three weed species that present an aggregated spatial distribution. This distribution allows the application of herbicides to be done in a localized way.

The mapping of the infestations is a tool that aids in weed control, bringing a triple benefit: greater economic returns, lower environmental impact and lower risk of weed resistance to herbicides, depending on the localized application, based on the actual infestation.

Considering the mean values, it was found that all species, except Conyza spp., presented values close to zero. Species Conyza spp. has shown an average of 40 plants $\mathrm{m}^{-2}$. This is due to the fact that the coverage of maize straw has a distribution that favors the emergence and development of this species over others found in the area (Oliveira Neto et al., 2013).

With respect to the infestation of C. echinatus, there is an average of 6 plants $\mathrm{m}^{2}$, the infestation is located on the edge area, and there is a lower infestation of Conyza spp. near the rural road.

With the results obtained and the infestation maps generated, it is possible to

Table 3 - Parameters of cross-validation of the theoretical models of semivariance adjusted for weeds. Engenheiro Beltrão, PR, 2013

\begin{tabular}{|l|c|c|c|c|}
\hline \multicolumn{1}{|c|}{ Specie } & Regression coefficient & Intercept (Y) & Standard error (SE) & $\mathrm{R}^{2} \underline{2} /$ \\
\hline Conyza spp. & 0.771 & 8.68 & 26.268 & 0.325 \\
\hline C. echinatus & 0.584 & 0.77 & 0.166 & 0.051 \\
\hline E. indica & 0.887 & 0.02 & 0.075 & 0.379 \\
\hline
\end{tabular}

1/ Pure nugget effect; $\stackrel{2}{2}$ Coefficient of determination. 


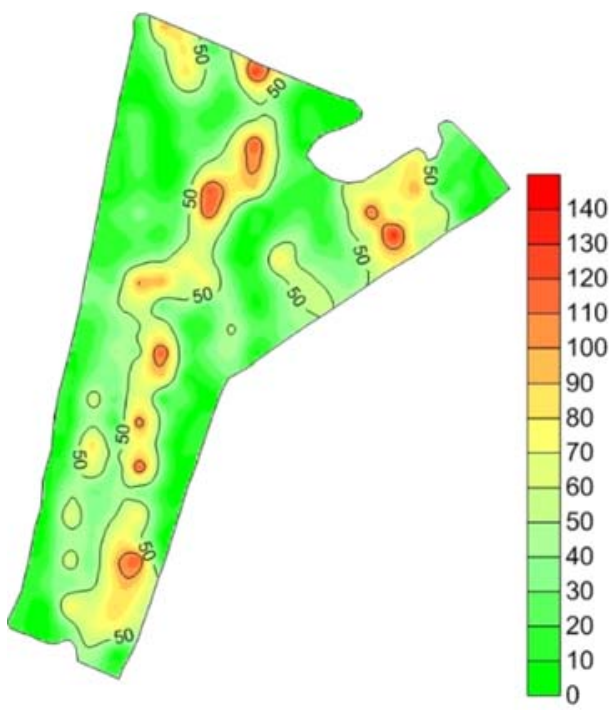

(A)

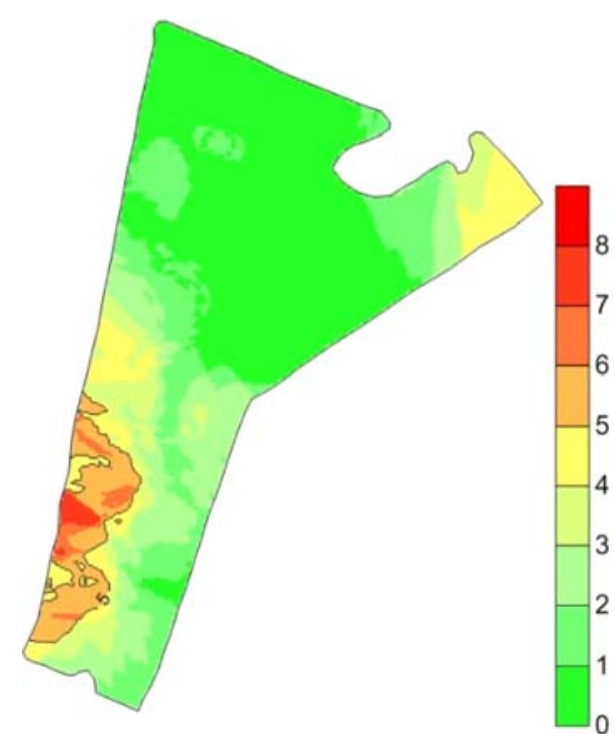

(B)

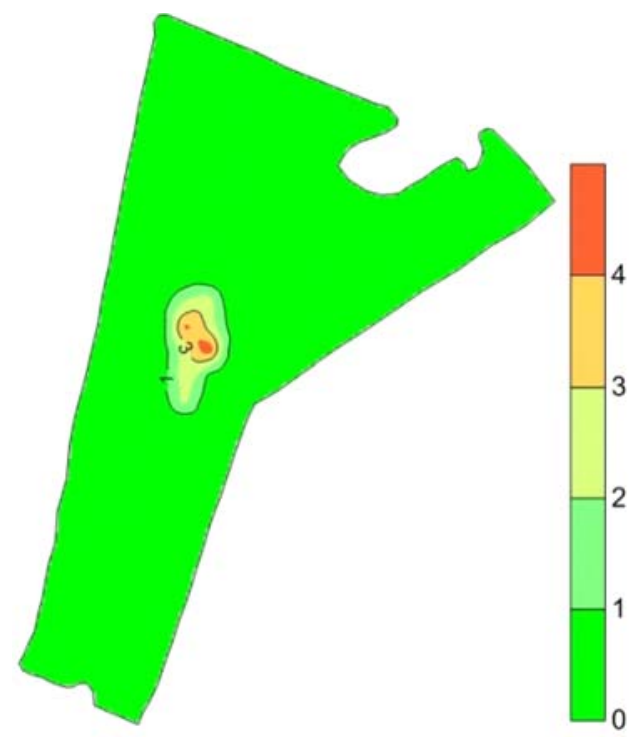

(C)

Figure 2 - Spatial distribution maps of weeds ( $\mathrm{m}^{-2}$ plants) in the study area: Conyza spp. (A), C. echinatus (B) and E. indica (C). Engenheiro Beltrão, PR, 2013.

define the localized application of herbicides, depending on the spatial variability. Different active ingredients can be used, according to the species and the occurrence of weed resistance to herbicides. With regard to resistance, herbicide glyphosate is the one with the biggest problem, especially for Conyza spp. This relates to the increased adoption of conservation production systems and a greater flexibility in applying the product in genetically modified crops resistant to this herbicide, resulting in an increased risk of selection of resistant biotypes of weeds, due to the higher pressure of imposed selection (Christoffoleti \& López-Ovejero, 2008).

When it comes to controlling monocotyledonous weeds, especially in the burndown time before the soybean crop, the control should be effective, since they cause greater losses regarding dicotyledonous weeds in tropical environments. 
Table 4 shows the area in ha and the percentage relative to the total area occupied by the species Conyza spp., Cenchrus echinathus and Eleusine indica. The species that occupied most of the area was Conyza spp., with 38.16 ha, which represented $65.7 \%$ of the total area of the sampled field (58.08 ha).

Table 4 - Area ratio occupied by weed species Conyza spp., Cenchrus echinathus and Eleusine indica. Engenheiro Beltrão, PR, 2013

\begin{tabular}{|l|c|c|}
\hline \multirow{2}{*}{\multicolumn{1}{|c|}{ Specie }} & \multicolumn{2}{c|}{ Occupied area } \\
\cline { 2 - 3 } & (ha) & $(\%)$ \\
\hline Conyza spp. & 38.16 & 65.7 \\
\hline Cenchrus echinathus & 23.82 & 41.0 \\
\hline Eleusine indica & 1.48 & 2.5 \\
\hline
\end{tabular}

Based on the above, it is concluded that I. grandifolia, G. spicatum, Richardia spp. and E. sonchifolia have not shown spatial dependence. Conyza spp., C. echinatus and $E$. indica have shown spatial dependence, and the spherical model was the one that best adjusted the data of species Conyza spp. and $E$. indica and the Gaussian model was the one that best adjusted the data of $C$. echinatus. The three species have an aggregated spatial distribution. The weed map is presented as a tool for localized control of these, making use of a more efficient, effective and economical herbicide.

\section{LITERATURE CITED}

BOTTEGA, E. L. et al.Variabilidade espacial de atributos do solo em sistema de semeadura direta com rotação de culturas no cerrado brasileiro. R. Ci. Agron., v. 44, n. 1, p. 1-9, 2013.

\section{CARLIN, H. L. S. Estimação dos parâmetros dos} semivariogramas utilizando algoritmos genéticos. 2010. 57 f. (Monografia) - Universidade Estadual do Oeste do Paraná, Marechal Cândido Rondon, 2010.

CARVALHO, F. T. et al. Manejo químico das plantas daninhas Euphorbia heterophylla e Bidens pilosa em sistema de plantio direto da cultura de soja. Planta Daninha, v. 20, n. 1, p. 145-150, 2002.

CARVALHO, J. R. P.; QUEIROZ, E. F. Uso de cokrigagem colocalizada na determinação da distribuição espacial de precipitação. Campinas: Embrapa Informática Agropecuária, 2002. (Comunicado Técnico, 21).
CORÁ, J. E. et al. Variabilidade espacial de atributos do solo para adoção do sistema de agricultura de precisão na cultura de cana-de-açúcar. R. Bras. Ci. Solo, v. 28, n. 6, p. 1013-1021, 2004.

CHRISTOFFOLETI, P. J.; LÓPEZ-OVEJERO, R. F. Resistência das plantas daninhas a herbicidas: definições, bases e situação no Brasil e no mundo. In:

CHRISTOFFOLETI, P. J. (Coord.). Aspectos de resistência de plantas daninhas a herbicidas. 3.ed. Piracicaba: Evangraf, 2008. p. 3-30.

\section{EMPRESA BRASILEIRA DE PESQUISA}

AGROPECUÁRIA - EMBRAPA. Centro Nacional de Pesquisas de Solos. Sistema brasileiro de classificação de solos. 3.ed. Brasília: Embrapa Produção da Informação; Rio de Janeiro: Embrapa Solos, 2013. 342 p.

GREGO, C. R.; VIEIRA, S. R. Variabilidade espacial de propriedades físicas do solo em uma parcela experimental. R. Bras. Ci. Solo, v. 29, n. 2, p. 169-177, 2005.

GUIMARÃES, E. C. Geoestatística básica e aplicada. Uberlândia: Universidade Federal de Uberlândia, 2004. 76 p.

INSTITUTO AGRONÔMICO DO PARANÁ - IAPAR. Cartas climáticas do Paraná. 2011. Disponível em: <http:// www.iapar.br/modules/conteudo/conteudo.php ?conteudo=597> . Acesso em: 6 set. 2013.

JAREMTCHUK, C. C. et al. Efeitos de sistemas de manejo sobre a velocidade de dessecação, infestação inicial de plantas daninhas e desenvolvimento e produtividade da soja. Acta Sci. Agron., v. 30, n. 4, p. 449-455, 2008.

JUNQUEIRA JUNIOR, J. A. et al. Continuidade espacial de atributos físico-hídricos do solo em sub-bacia hidrográfica de cabeceira. Ci. Agrotecnol., v. 32, n.3, p. 914-922, 2008.

LIBARDI, P. L. et al. Variabilidade da umidade gravimétrica de um solo hidromórfico. R. Bras. Ci. Solo, v. 20, n. 1, p. 1-12, 1996.

LORENZI, H. Manual de identificação e controle de plantas daninhas: plantio direto e convencional. São Paulo: Instituto Plantarum, 2000. 339p.

OLIVEIRA NETO, A. M. et al. Controle cultural. In: CONSTANTIN, J.; OLIVEIRA JR, R. S.; OLIVEIRA NETO, A. M. Buva: fundamentos e recomendações para manejo. Curitiba: Omnipax, 2013. p. 33-40.

SHIRATSUCHI, L. S. et al. Aplicação localizada de herbicidas. Planaltina, DF: Embrapa Cerrados, 2003. 18p.

SHIRATSUCHI, L. S.; FONTES, J. R. A. Levantamento florístico de plantas daninhas em lavoura de milho cultivada no Cerrado de Goiás. Planaltina, DF: Embrapa Cerrados, 2005. 19p.

Planta Daninha, Viçosa-MG, v. 33, n. 1, p. 157-164, 2015 
VIEIRA, S. R. Geoestatística em estudos de variabilidade espacial do solo. In: NOVAIS, R. F.; ALVAREZ V., V. H.; SCHAEFER, C. E. G. R. (Org.). Tópicos em ciência do solo, Viçosa, MG: Sociedade Brasileira de Ciência do Solo, 2000. v. 1. p. 1-54.

WARRICK, A. W.; NIELSEN, D. R. Spatial variability of soil physical properties in the field. In: HILLEL, D. (Ed).

Applications of soil physics. New York: Academic Press, 1980. p. 319-44.
ZANIN, G. et al. Incorporation of weed spatial variability into the weed control decision-making process. Weed Res., v. 38, n. 1, p. 107-118, 1998.

ZIMBACK, C. R. L. Análise espacial de atributos químicos de solos para fins de mapeamento da fertilidade do solo. 2001. 114 f. Tese (Livre-Docência) - Faculdade de Ciências Agronômicas, Universidade Estadual Paulista, Botucatu, 2001. 